\title{
ÚJ PARADIGMA AZ OKTATÁSBAN - A KÉPEK ELSŐDLEGESSÉGE
}

\section{A NEW PARADIGM IN EDUCATION - THE PRIORITY OF THE IMAGE}

\author{
Benedek András \\ az MTA doktora, egyetemi tanár, MTA-BME Nyitott Tananyagfejlesztés Kutatócsoport \\ benedek.a@eik.bme.hu
}

\begin{abstract}
ÖSSZEFOGLALÁS
A tanulmány a 17. században formálódott és Comenius nevéhez kapcsolódó oktatási paradigma pedagógiai keretekben történő újrainterpretálására vállalkozik. A vizualitás által a tanulásra gyakorolt hatások jelentőségének felismerése az elmúlt évtizedekben számos elméleti és gyakorlati elemzésben (Arnheim, Ferguson, Nyíri) megjelent. Speciális dimenzió az oktatásban és nevelésben az infokommunikációs technológiák (IKT) használata, melyekkel minden eddiginél jobban törekszünk a képek alkalmazására. A multimodalitás új típusa a jelenlegi tanítás-tanulás számára szakmódszertani megújulási lehetőséget kínál, ezért a hallgatók által bármikor és bárhol elérhető új infokommunikációs lehetőségeket tudatosan lehet és kell alkalmaznunk. A tanulmány összegzi azokat az elmúlt évtizedben született kutatási eredményeket (Benedek, Molnár, Nyíri), melyek a képek kreatív alkalmazásával és egy szakmódszertanilag megalapozott nyitott struktúra kialakításával szemléltetik a lehetőségeket. A nyitott tartalomfejlesztési (OCD) paradigma új pedagógiai válaszokat adhat a jelenlegi mindennapi oktatási feszültségek kezeléséhez.
\end{abstract}

\section{ABSTRACT}

The talk re-interprets the paradigm by $17^{\text {th }}$ century Comenius (Orbis Pictus) and its impact on education within the framework of today's pedagogical thinking. The impact exerted by visual effects on learning-generated epochal impulses in a number of theoretical and practical experiments (Arnheim, Ferguson, Nyíri) will be analysed. One of the special dimensions of the transformation going on in education and pedagogy these days, which is perceivable by ICT applications becoming more and more commonly used, is that we strive to apply images more explicitly than ever before. In fact a new type of multi-modality, offering effective methodological utilization in current teaching and learning, is taking form. We can and must use consciously this new possibility which has info-communication potentials and is available by the students practically anytime and anywhere. The talk summarizes the main findings of our researches (Benedek, Molnár, Nyíri) conducted during the past decade, demonstrating that it is possible to use images creatively and in a methodologically well-grounded way in open structures. The paradigm of open content development (OCD) may give new pedagogical answers to the tensions being present in everyday education.

Kulcsszavak: oktatás, oktatásinnováció, tanuláselmélet, tanulási környezet, vizuális tanulás

Keywords: education, education innovation, learning theory, learning environment, visual learning 


\section{BEVEZETÉS}

Az oktatás összetett társadalmi folyamat, melybe mindnyájan valamikor és valahogy in situ bekapcsolódunk, ugyanakkor relatíve lassú változása miatt a lényegi változások történeti dimenziókban érzékelhetők. Ezért az oktatás-nevelés ügye a mindennapi jelentőségén túl a tudományos érdeklődés szempontjából is kitüntetett tárgynak tekinthető. E komplex kérdéskörrel a kezdetektől foglalkozik a tudomány, az elsők között Platón a közügyek gyakorlásának lényeges feltételeként tekintett a nevelésre. Napjainkban az akadémiai gondolkodás szintjén a tudomány felelősségvállalásának erősödését jelzi a szakmódszertani fejlesztési program megindítása (2016), s az MTA Közoktatási Elnöki Bizottság legújabb szerepvállalása. Jelenünkben a társadalmi gyakorlathoz szorosan kapcsolódó pedagógia s az ahhoz kapcsolódó neveléstudomány a hazai akadémiai diszciplínák perifériáján helyezkedik el, ezért az interdiszciplináris megközelítések olyan potenciált jelentenek, melyekre az oktatás komplexitása miatt mint a változási folyamatok releváns elemzési lehetőségére tekinthetünk.

A tradíciókhoz erősen kötődő oktatás-nevelés esetében mindig is merészség új paradigmákról beszélni, abban az értelemben, hogy a gondolkodásnak, értékeknek és módszereknek együttesét egy adott időszakban jellemzőnek tekintjük. Írásomban a vitát vállalva kettőt is megemlítek. Elsőként a meglehetősen régi, a 17. századi comeniusi (különösen az Orbis Pictus által szemléletesen megjelentetett) paradigmára, a szemléltetés, a képek oktatásban játszott szerepének első felismerésére utalva megállapítható, hogy a középkorban megjelent, akkor eredendően új tanítási-tanulási paradigma a ma élő generációk többségének oktatására hatással volt és van. Lényegesebb ugyanakkor a második megállapítás: a 21. századba lépve ezt a sok évszázados paradigmát újraértelmezendőnek, az oktatás alapvetően megváltozott környezetében és a vele szemben támasztott új követelmények függvényében átalakulónak vélem, s igyekszem bizonyítani, hogy egy újabb paradigma formálódik, és egyre inkább érvényesül az oktatásban napjainkban és feltételezhetően a közeli jövőben.

\section{INTERDISZCIPLINÁRIS HÁTTÉR}

Az ezredfordulót követő évtized derekán, Nyíri Kristóffal a képek emberi tevékenységekben játszott szerepéről folytatott filozófiai indítású, de az oktatás megújulásának problémájával foglalkozó interdiszciplináris keretekben táguló körben zajló szakmai beszélgetéseink adtak inspirációt, hogy a mobilkommunikációs eszközök tanulásra gyakorolt egyre sokrétűbb hatásának elemzéseire irányuló kezdeményezést tegyünk. Akkori, az MTA és a T-Mobile által támogatott interdiszciplináris társadalomtudományi kutatásaink a 21. század kommunikációjá- 
nak vizsgálatára irányultak, felismerve a hálózati rendszerek, az interaktivitás online és a mobil tanulás elterjedésének hatásait. ${ }^{1}$ Az interdiszciplináris tudományos dialógus lehetőségét keresve hívtuk életre 2009 őszén a Budapesti Müszaki és Gazdaságtudományi Egyetemen a Képi Tanulás Mühelyét (nemzetközileg ismertebb nevén: VLL - Visual Learning Lab).

A visuality lehető legszélesebb értelmezése számos diszciplína képviselőjének érdeklődését felkeltette, a szakmai fórum programjába bekapcsolódtak a nyelvészek, esztéták, szociológusok, valamint a müszaki tudományok képviselői. Örvendetes módon a kezdetektől érzékelhető volt, s figyelemre méltó előadásokkal kapcsolódott a nemzetközi részvétel is (James Elkins, Theo Hug, Berry Smith) a távoktatás és m-learning témaköreivel gazdagítva a tematikát. ${ }^{2}$ A nemzetközi tudományos érdeklődés igénye és a párbeszéd lehetőségének a felismerése vezetett el oda, hogy 2010 és 2016 között évente megrendezésre került a Visual Learning Conference, mely kezdeti szerény méretei ellenére - harminc-negyven tudományos előadás kezdetben, 2018-ban pedig már mintegy száz előadás - jelentős fórummá nőtte ki magát, melyen európai és tengeren túli kutatók a tematikájában is differenciálódó visuality modern értelmezéséhez járultak hozzá,

Az elmúlt évtizedre visszatekintve megállapítható, hogy a Visual Learning konferenciák szerepe túlnyúlt a szakmai tudományos dialógusok új fórumának megteremtésén. Az elektronikus nyilvánosság - absztraktok és prezentációk -által biztosított lehetőségen túl évente összeállításra került egy-egy lektorált kötet, mely a konferenciákon elhangzott előadások szerzői közül mintegy harmaduk esetében megfogalmazott felkérésre készült tanulmányokat tartalmazta. ${ }^{3}$

${ }^{1}$ Mobiltársadalomkutatás, illetve Mobil Studies címmel, a kutatásokat vezető Nyíri Kristóf szerkesztésében jelentek meg 2006 és 2008 között az eredményeket összegző tanulmányok.

${ }^{2}$ A VLL első megbeszéléseinek témája James Elkins Visual Practices Across the University (Elkins, 2007) munkájának feldolgozása volt (2009. november 4.), a következő évben személyes előadással járult hozzá a VLL programjához Theo Hug professzor (University of Innsbruck), Media Competency and Visual Literacy - Conceptual Considerations elöadása (2010. október 6.), a tengerentúlról Skype-konzultációt vállalt How Vision Works címmel Barry Smith professzor (University at Buffalo) (2011. november 3.).

${ }^{3}$ Érdemes utalni arra, hogy milyen módon változott a ma már sorozatként ismert Visual Learning kötetek tematikája. 2011-2017 között hét kötet jelent meg a Peter Lang Internationaler Verlag der Wissenschaften Kiadónál (Frankfurt am Main) a Visual Learning sorozatban. Az első öt kötetet 2011-2015 között Nyíri Kristóffal közösen szerkesztettük, s a címeik is érzékeltetik a tematika interdiszciplináris kezelését: Image in Language: Metaphors and Metamorphoses (2011), The Iconic Turn in Education (2012), How to Do Things with Pictures: Skill, Practice, Performance (2013), The Power of the Image - Emotion, Expression, Explanation (2014), Beyond Words: Pictures, Parables, Paradoxes (2015), valamint a legutóbbi két, Veszelszki Ágnessel közösen szerkesztett kötet címei: In the Beginning was the Image: The Omnipresence of Pictures: Time, Truth, Tradition (2016), Virtual Reality - Real Visuality: Virtual, Visual, Veridical (2017) érzékeltetik, hogy a komplex értelmezés számos dimenzióban adott interpretációs kereteket a más diszciplínákhoz való kapcsolódások elemzéséhez. 
Lényeges arra utalni, hogy az elmúlt évtizedekben a vizuális hatások tanulásra gyakorolt jelentőségének felismerése számos elméleti és gyakorlati felvetésben (Arnheim, 1954, 1969; Ferguson, 1977; Nyíri, 2007a,b) jelentős impulzusokat adott. Az oktatásban-nevelésben napjainkban zajló transzformációs fordulat egyik, éppen az infokommunikációs technológiai (IKT) alkalmazások általánossá válásával érzékelhető sajátossága az, hogy képek tudatos alkalmazására jóval határozottabban törekszünk minden eddiginél. Ezt a szinte közhelyszerủ megállapítást ugyanakkor nem is könnyủ a mindennapi pedagógiai gyakorlatban érvényesíteni, mivel ennek a formális tanulásban a tanárok és iskolák intézményesült tudásának tradicionális rendszere jelentős tehetetlenséggel ellenáll. A VLL interdiszciplináris keretei, az abban időről időre megjelenő új eredeti gondolkodás, diszciplínák egymást is serkentő kezdeményezései, a nemzetközi kitekintés és kölcsönös reflexió olyan késztetést jelentett, melyben az új jelenségek felismerése szükségszerủen elvezetett az oktatási, konkrétan tanítási-tanulási paradigmák kérdésének felvetéséhez.

\section{KIINDULÁSI PONT: COMENIUS PARADIGMÁJA}

A középkor méltán legnagyobb hatású „reformpedagógusa”, Comenius az 1657-ben kiadott Didactica Magnában a filozófiai „közügy” felismerésének fontosságát hangsúlyozva sürgette az oktatás megújítását, a fiatalok nevelését tartva a politikai, társadalmi és vallási megújulás első lépcsőfokának. „Az oktató a tanulók érzékeit és képzeletét megragadó képekkel kísérje magyarázatát, hogy a látható dolgokat láthassák, ami hallható, azt meghallhassák, a szagokat megszagolhassák, az ízeket megízlelhessék és a tapintható dolgokat megtapinthassák.” (Eco, 2016, 207.) Ez a felfogás az adott korban éles paradigmaváltást jelentett a verbális tanítás zárt, dogmatikus, a szövegek magyarázatára épülő világfelfogással szemben, s az oktatás tartalmi-módszertani megújításának centrumába a korszerü tanórai, tankönyvi szemléltetést állította. Comenius azt hangsúlyozta ki, s ebben korában az első volt, hogy a tanuló közvetlenül a képek révén sajátítsa el azt, amiről a tanításban szó esik. Korának világszemléletét megpróbálta egyfajta logika szerint csoportosítani, az elemi fogalmak szerint, melyekre a szavak utalnak (a világ teremtése, elemek, ásvány-, növény- és állatvilág stb.). E rendszert többnyelvü tankönyvbe is foglalta 1658-ban Orbis sensualium pictus quadrilinguis, közismert nevén az Orbis Pictus képes többnyelvű tankönyvében, mely évszázadokra a szemléltető tankönyvek mintájává vált. Az egyetemes nyelvet kereső kísérlet egy utópikus látomás volt, de a multimodalitás felismerésével olyan korszakváltó pedagógiai módszert is jelentett, mely a következő három évszázadra az oktatás módszertani megújulásának progresszív irányzatává vált. 
Az oktatás képi szemléltető eszközökkel történő módszertani korszerüsítési folyamatát a tankönyvek fejlödésének folyamata jól szemlélteti. Müvelödéstörténeti szempontból meggyőzően érzékeltethető, akár a nemzeti oktatás keretein belül, hogy a könyvnyomtatás elterjedésével a tömegoktatás tankönyvei miként váltak a tanítás-tanulás olyan kulturális objektivációivá, melyek az adott kor tudományos, ideológiai állapotát-törekvéseit tükrözték. A képek szerepe ugyanakkor az ideológiai hatások erősödésével fordított arányban csökkent. A változás egyik figyelemre méltó vonulata, hogy a tanítással-tanulással kapcsolatos új definíciók a képiség szerepére számos nyelvben erőteljesen utalnak. A kép-képzés-képzettség, Bildung-Ausbildung, образ-образования, image-formation-imagination kifejezések erre szemléltető példát mutatnak.

A comeniusi paradigma újraértelmezésének szükségességét ugyanakkor egyre több tényező, fejlődési sajátosság is sürgette. Az ezredforduló időszakában már a tudományos hivatkozások szintjén is komoly impulzust adott egy eredendően új, s egyre többször idézett jelenség, a konnektivista tanuláselmélet megjelenése és a tanulásra gyakorolt hatása. Az új oktatásinnovációs történésekre mint lényeges tendenciákra hivatkozhatunk. Kutatásaink éppen ebben az időszakban a tanulási környezet interaktív eszközök által történő átalakulásával, a tudást képi úton is megjeleníthető technikák térhódításával és az új eljárások individualizációjával kapcsolatosan vezettek el új felismerésekhez. Feltételeztük, hogy a szerves tanulási környezetek - társadalmi és technológiai oldalát egymással nem szembeállító - oktatáselmélete az eddigi mechanikus szemlélet kritikájával a pedagógiai gondolkodás szélesebb spektruma előtt nyitja meg a tanítás-tanulás konstruktív kezelésének lehetőségét. Az elektronikus tanulási környezetek sajátosságait az elméleti megközelítések és modellek szintjén elemezve megállapítható, hogy korántsem befejezett, lezárult folyamatokról van szó, sőt a felgyorsult technológiai fejlődés nem fékeződik, ezért kulturális és társadalmi hatásai nehezen prognosztizálhatók. Ennek ellenére éppen a vizuális tanulás legújabb fejlődéstörténete konstruktív elemzési kereteket kínál a jelenségek elméleti és gyakorlati vizsgálatához, s felbátorít egy új, formálódó oktatási paradigma felvázolására.

\section{4. ÚJ PARADIGMA FELÉ}

Az oktatás fejlödéstörténete szerint az elmúlt évszázadokban végbement változás figyelemre méltó vonulata, hogy a tanítással-tanulással kapcsolatos új definíciók az imagination szerepére egyre erőteljesebben mutatnak rá. Ahogy a hagyományos táblák funkcióit az audiovizuális eszközök (diavetítők, epidiaszkópok, írásvetítők, majd az intelligens táblák) egyre dinamikusabban bővítik, úgy a modern oktatáselmélet az újabb évezredbe lépve érzékelhető módon „hirtelen átlépett” a folyamatos tanulás évszázados pedagógiai paradigmájának lassú térnyerésén. 
A tanulási tér kitágulásának, a bárhol és bármikor kommunikálni (ubiquitous communication) és tanulni elvi lehetőségének valóságossá válásával új tanulási környezet, s az abban használt egyre „okosabb” mobilkommunikációs eszközök jóvoltából új, a tanulás hatékonyságát is érdemben érintő funkciók jelentek meg.

Az ezredfordulót követően formálódó új pedagógiai paradigma az úgynevezett netgeneráció vagy éppen a homo interneticus (Goldhaber, 2004), az internethasználatot már természetszerüleg ismerő és alkalmazó nemzedék számára az osztálytermek és tankönyvek világából kilépve kínál tanulási lehetőséget egy olyan világban, s ez a ma legnagyobb ellentmondásainak egyike, melyben az iskola és a pedagógusok jelentős hányada még a 20. századra jellemző módon szervezi a nevelés-oktatás folyamatait. A hagyományos közösségek mellett újabb és rendkívül gyorsan hatalmas méretekben szerveződő közösségek is létrejönnek, példa erre a Facebook és a Twitter, melyek társadalomformáló hatásukon túl oktatási-nevelési kihívásként is jelen vannak. A könyvnyomtatás korszakában a környezet szemléltetését támogató kognitív funkciók eszköze volt még a nyomtatott kép, a könyvlap, azonban ezt néhány évtized alatt felváltotta az információs társadalom emblematikus felülete, a - már a kisgyermekek által is felismert, müveletvégzésre is képes - érintőképernyő. A történeti homo oralis verbális képességeire az elmúlt századokban ráépült a homo typographicus, aki már nyomtatott forrásra építi tudását, s jelenünkben már mint homo interneticus a virtuális környezetben létrehozott képi effektusok tömegével késztet másokat is interakciókra.

Az oktatásfejlesztés elkerülhetetlenségét az e témában megjelenő hatalmas számú publikáció is érzékelteti. Különösen nemzetközi szinten nőtt meg a tanulás új formáival, módszertani és technikai megújulásával kapcsolatos közlemények száma. Egyfelöl az oktatás új paradigmáit értelmező s a pedagógiai innovációra is globális hatást gyakorló képviselői (Kop-Hill, 2008) a klasszikus pszichológiai és filozófiai (behaviorista, kognitív, konstruktív) iskolákra alapozva, másfelől a modern kommunikációs technológiák hatására jelentős impulzív fordulatot tettek a hálózati sajátosságok elemzésének irányába az ezredforduló időszakában. Az elmúlt években a hálózatalapú tanulás különösen jelentős hatású tanuláselméleti irányzattá vált, mivel az a hálózatelméletek, az informatika, a web 2.0 elvi alapjainak pedagógiai alkalmazását jelenti. George Siemens 2005-ben publikált elmélete szerint a konnektivizmus kifejezetten a digitális korszaknak szóló tanuláselmélet. Ez az elmélet ${ }^{4}$, definiálva a kapcsolódó fogalmakat, az új pedagógiai

\footnotetext{
${ }^{4}$ A konnektivizmus konzervatív bírálói szerint mindez inkább egy új pedagógiai szemlélet, mely az informatika, a pedagógia és a hálózatkutatás interdiszciplináris találkozásába helyezhető, s mely a konstruktivista elmélethez is kapcsolható. A tanuláselméleti felfogások közül a konstruktivista felfogás ugyanis magában hordozta már a hálózati jelleget, erre példák a közösségi oldalak. A tudástartalmak hálózaton történő közös kezelésére a legismertebb példa, mely az új konnektivista felfogás jegyeit hordozza, a Facebook közösségi portál.
} 
paradigma számára azért is fontos, mert középpontjába a hálózatelméletet és ennek tudásmenedzsmentbe emelését tette.

A konnektivista tanuláselmélet térnyerése azzal is összefügg, hogy a progresszív oktatási intézmények, s különösen a felsőoktatási intézmények jelentős köre, alkalmazkodva az új hallgatói attitüdhöz, szokásrendszerhez s az új tanulási formákhoz, az utóbbi évtizedben e-learning alkalmazásokat részben-egészben adaptáló oktatási módszerekre tért át. Ezek a rendszerek online, illetve webalapú tanulástámogató rendszerek, a hálózati csomópontok közti folyamatos kommunikációt szinkron vagy aszinkron formában teszik lehetővé a résztvevők (oktató-hallgató, oktató-oktató és a hallgató-hallgató) között. Az új tanuláselmélet a tanulást olyan folyamatnak fogja fel, amelyben az informális, hálózatba szervezett, elektronikus eszközökkel támogatott információcsere a csomópontok között meghatározó szereppel bír. A tudás megszerzése olyan folyamat, melynek során a specializált csomópontok információforrásokhoz kapcsolódnak.

A mai korszerü nyitott hozzáférésü e-learninges tananyagok (OER - Open Education Resources) arra az alapkérdésre keresik a választ, hogy miként lehet az oktatás tartalmát, az elsajátítandó tananyagot nyitottá tenni, olyan struktúrákban közvetíteni, melyek vonzóak, motiválóak a tanulók számára. Elvi, majd az MTA Tantárgy-pedagógiai Kutatási Programjának keretei között végzett gyakorlati munkáinkban is lényeges, hogy az oktatás tartalmi elemeinek közvetítésében jelentős potenciált hordoz a vizuális elemek számának és minőségének növelése, az új technikai keretek adottságainak kihasználása és ezzel a tanulásban részt vevők aktivitásának növelése. Ezt a folyamatot sajátos módon a filozófusok már az ezredforduló idején felismerték, s mint az eredeti vizuális kommunikációhoz való visszatérést értelmezték. Vagyis az emberi kommunikáció természetes módjának tekinthetjük a képi, ikonos vagy éppen comicsok segítségével történő kommunikációt, melyben a sajátos, relatíve rövid narrációk figyelemre méltó megjelenései a videoklippek (elterjedésük különösen a reklámok, majd a YouTube jóvoltából az elmúlt évtizedben a tizenévesek körében rapid módon végbement).

A hagyományos tanterem és az évszázados tradíciókat követő tankönyvek a ma embere által igényelt képi tartalmak közvetítésére egyre kevésbé vállalkoznak. Érdekes összehasonlítani a kisgyermekkori nevelés színhelyeit - óvoda, alsó tagozatos osztályterem - azok tárgyi környezetét, melyekben a képek, tablók lényegesen nagyobb szerepet kapnak, mint az oktatás magasabb szintjén a nap jelentős részében „otthont adó” iskolai tantermek. Az ősi fekete tantermi táblaírásvetítő-intelligenstábla korszakváltásai sok-sok évtizeden keresztül, a legutóbbi ötven évben mentek végbe, de az igazán jelentős fordulatot az érintőképernyős készülékek tömeges elterjedése és a személyes használat már kisgyermekkorban elkezdődő gyakorlata hozta. S ebben a fordulatban az iskolán kívüli világ sokkal gyorsabban és kreatívabb módon változott az utóbbi másfél-két évtizedben. A ké- 
pek készítése, üzenettartalmakkal történő kiegészítése, a műfaji sajátosságok videó, flash, animációk - alkalmazása ma már a mindennapok kommunikációjának egyre általánosabb gyakorlatává vált. A képek tárolása, szerkesztése, továbbá megosztása és a hálózati kommunikációs rendszerekben történő forgalmazása az elmúlt évtizedben alapvető társadalmi tevékenységgé lett, melyet eddig csupán szerény mértékben tettünk részévé az iskolai tanításnak és tanulásnak. A modern tantervelmélet a kognitív és az affektív funkciók komplex hatására már évtizedekkel ezelőtt felhívta figyelmet, ami a képek alkalmazásának pedagógiai jelentőségét különösen fontossá teszi.

\section{IGÉNY A SZAKMÓDSZERTANI FORDULATRA}

A 2016-ban elkezdett kutatásainkat megelőzően, évtizedünk elején a hagyományos tananyagok digitalizálásának hatásait, valamint a nyitott tananyagfejlesztés lehetöségeit vizsgáltuk IKT-környezetben (Benedek-Molnár, 2015), egyetemi ${ }^{5}$ szinten. Lényegi megállapításunk volt, hogy a szekvenciálisan felépített zárt tananyagstrukturák két alapvető problémával szembesülnek napjainkban. Egyfelöl az oktatási tartalmak a zárt és nehezen kezelhető szerkezetekben nem igazán alkalmasak a változásra, nehézkes az up-date-elés, s az ezzel kapcsolatos szakmai motiváció rendkívül alacsony. Másfelől a mai IKT-környezetben a hálózatosodott tudás elsajátításának lehetőségeit megismerve a fiatalok - tanulók és hallgatók sem kellően motiváltak a hagyományos tananyag befogadására, mélyebb feldolgozására. E megállapítás különösen annak fényében lényeges, hogy a fiatalok kommunikációs gyakorlatában - egymás között a közösségi alkalmazások nyújtotta szolgáltatásokat igénybe véve (például Facebook), hírek, blogok olvasásakor - a képi üzenetek egyértelmủen dominálnak. Bár a hagyományos tantermi konstelláció alapeleme a kép (íráskép és rajz), a mindenki által már formálódásában is látható tábla, azonban hagyományos eljárásokkal készült tananyagaink számos esetben csak szerény mértékben tartalmaznak képi elemeket. Ennek praktikus

${ }^{5}$ 2014-2015-ben a Budapesti Műszaki és Gazdaságtudományi Egyetemen egy digitális tananyagfejlesztési projekt keretei között huszonkilenc olyan digitális jegyzetet készítettünk, melynek írói - kiváló szakemberek - kötelezően részt vettek tréning formájában olyan felkészítéseken, mely a projektvezetés a korszerủ OER fejlesztési elvei szerint, kifejezetten jelentős számú vizuális objektumok tananyagba történő beépítését kérte a szerzőktől. A projekt keretében készített differenciált szakmai tartalommal, de zömmel a szakmai tanárképzés számára tervezett tíz, véletlenül kiválasztott elkészült jegyzetet elemezve megállapítható, hogy az átlagosan 4,5 íves 90 oldal terjedelmü, egyébként képernyőre optimalizált jegyzetekben összesen 602 képi objektum (ábra, fotó, táblázat) került beszerkesztésre. Ez azt jelenti, hogy az online tanulást támogató új jegyzetekben is átlagosan 1,5 oldalanként van csupán képi objektum. Ezeknek a kutatási eredményeink alapján 42\%-a táblázat, 36\%-a ábra (rajz) és csupán 22\%-a, mintegy ötöde volt fotó. 
oka a szövegdominanciára épülő tananyag-konstrukciós hagyományokon túl a limitált tankönyvi terjedelem, a képek és színek nyomdai kezelésének nehézségei, sokszor költségemelő hatása.

A képek oktatási célú alkalmazása önmagában is a multimodalitásra épülő módszertan gyakorlati lehetőségét hordozza, különösen akkor, ha jól meghatározott kérdésekre adott válaszokhoz használjuk fel a képi konstrukciókat, illetve új kérdésekre, problémákra hívjuk fel a figyelmet a képek szemléltető erejével. Ezzel el is érkeztünk új orientációs projektjeink szemléltető bemutatásához, melyek az útkeresést is érzékeltetik. Egyfelöl egy elektronikus oktatási platform keretében a multimodalitás alkalmazására példa a rendszerelméleti megközelítést középpontba állító SysBook (Vámos et al., 2016; Benedek-Horváth, 2016), melyet néhány éve kezdtünk el oktatásmódszertani célból fejleszteni az MTA Számítástechnikai és Automatizálási Kutatóintézetének (SZTAKI) munkatársaival, másfelől a szakképzésben igényelt szakmódszertani megújulást támogató ún. OCD ${ }^{6}$-modell (Benedek, 2016), mely a nyitott tananyagfejlesztés bevezetésére vállalkozott az MTA-BME Nyitott Tananyagfejlesztés Kutatócsoport keretében.

Az elektronikus tananyag-konstrukciók esetében a médiaelemek alkalmazása egyre inkább terjed, annak ellenére, hogy a kezdeti időszakban a fejlettebb dinamikus és interaktív médiaalkalmazás sokszor az internet sávszélessége és a szükséges tárkapacitás korlátaiba ütközik. Érdemes a már hivatkozott forrásra ismételten utalni: a leginkább kedvelt oktatási célú programok körében egyre jobb helyezéssel rendelkeznek a felhöszolgáltatásokkal megtámogatott olyan programok, mint a Google Docs, Google Search, Dropbox. A hálózati tanulás és az azt támogató komplex hálózati szerkezetben formálódó tananyagok elterjedése és használata iránti növekvő igény egyértelmủen jelzi a felhőszolgáltatások szükségességét az oktatásban és a tananyagfejlesztésben. E felismerések játszottak szerepet abban, hogy új fejlesztéseink 2016-tól határozottan a vizuális tartalmi elemek kezelésének egyik lehetőségeként tekintettek a nyitott tartalomfejlesztésre az oktatásban.

\section{6. ÖSSZEGZÉS}

Jelen írás keretei között mindenekelött az oktatás módszertani megújulása egyik lehetőségeként a képi kommunikáció, az imagination mindig is létező, de napjainkban különösen jelentős gyakorlati lehetőségeire mint innovációra szerettem volna utalni. Az elvi felismerés már adott, ha kaotikusnak is tủnnek a legújabb kísérletek, érzékeltetik a változtatás szándékát minden érintett

\footnotetext{
${ }^{6}$ Open Content Development.
} 
részéről. Példaként hivatkozhatunk a Sysbook- és az OCD-fejlesztésekre, melyek jellegüket tekintve különbözőek, az első a „hagyományos” internetes portálfunkciók együttesében, a második a tartalmi fejlesztés (tananyagfejlesztés) kollaboratív (kooperatív tanulási környezetben megvalósuló) módszertani lehetôségét szemlélteti. S e ponton ezt, az új tanítási-tanulási paradigma általános jellemzőinek meghatározási kísérletét a példák részleteinél is fontosabbnak tartom. A változás egy új oktatási paradigma érvényesülését és az új tanítási-tanulási kommunikációs folyamat egyik lényeges jellemzőjét érzékelteti, melyre az oktatás-nevelés innovációjának különösen nyitottnak kell lennie. Joggal felvethető ugyanakkor a kérdés: melyek a megkülönböztető, új elemei annak az oktatásnak vagy inkább tanulási paradigmának, melyet napjaink változásai érzékeltetnek, s egyre inkább általánosan, társadalmi méretekben érvényesülnek a tanulásban?

Elsőként lényeges új elem, hogy nem a tanitás határozza meg elsödlegesen a tanulás módszereit, szemben a múltbeli osztálytermek kizárólagos világával, $h a-$ nem az alkalmazott eszközök, s ezek jelentös mértékben az IKT fejlödési trendjei mentén formálják az egyén tanulási környezetét. Vagyis a tanulási környezet sajátosságaihoz kapcsolódó tanítási módszerek egyre általánosabbá válnak.

Második sajátosság, hogy az új szerves tanulási környezet alapvetően a hálózatokra jellemzö módon formálódik és müködik, ami a tudás, a közvetített tartalom megosztásának és fejlesztésének minden eddiginél dinamikusabb és potenciálisan hatékony rendszerét teszi kialakithatóvá.

Harmadik lényegi jellemző: ahogy a képi elemek újszerủ tudásközvetítést tettek lehetővé a comeniusi paradigma által, úgy a képek, különösen a mozgóképek generális szerepüket nem csupán megörzik, hanem a tartalom konstruálása, megosztása és befogadása során érzékelhetöen hatékonyan képesek a tanulási folyamatot innovativan támogatni.

Végül lényeges annak változatlan megerösítése, hogy a tanulás alapvetően társas tevékenység, még akkor is, ha modern világunkban a virtuális elemek megjelenése az oktatás konzervatív intézményi szintjén érthető feszültségeket is kelt. A képi tartalom fejlesztésével és közvetítésével másoknak, közösségeknek szóló üzenetek fogalmazódnak meg, s ezek hatalmas pedagógiai potenciált hordoznak a tanítás-tanulás megújításában. 


\section{IRODALOM}

Arnheim, R. (1954): Art and Visual Perception: A Psychology of the Creative Eye. Berkeley, CA: University of California Press

Arnheim, R. (1969): Visual Thinking. Berkeley, CA: University of California Press

Benedek A. (2016): Nyitott tananyag-fejlesztési modell (OCD), MTA-BME Nyitott Tananyagfejlesztés Kutatócsoport Közlemények, 1, 5-21.

Benedek A. - Horvath Cz. J. (2016): Case Studies in Teaching Systems Thinking. In: Mikuláš, H. - Rossiter, A. (eds.): Preprints of the 11 ${ }^{\text {th }}$ IFAC Symposium on Advances in Control Education. Bratislava: IFAC, 286-290.

Benedek A. - Molnár Gy. (2015): New Approaches to the E-content and E-textbook in Higher Education. In: Gómez Chova, L. - López Martínez, A. - Candel Torres, I. (eds.): INTED2015 Proceedings: $9^{\text {th }}$ International Technology, Education and Development Conference. International Academy of Technology, Education and Development (IATED), 3646-3650.

Benedek A. - Nyíri K. (eds.) (2011): Images in Language: Metaphors and Metamorphoses (Series Visual Learning 1). Frankfurt/M.: Peter Lang

Benedek A. - Nyíri K. (eds.) (2012): The Iconic Turn in Education (Series Visual Learning 2). Frankfurt/M.: Peter Lang

Benedek A. - Nyíri K. (eds.) (2013): How to Do Things with Pictures: Skill, Practice, Performance (Series Visual Learning 3). Frankfurt/M.: Peter Lang

Benedek A. - Nyíri K. (eds.) (2014): The Power of the Image - Emotion, Expression, Explanation (Series Visual Learning 4). Frankfurt/M.: Peter Lang

Benedek A. - Nyíri K. (eds.) (2015): Beyond Words: Pictures, Parables, Paradoxes (Series Visual Learning 5). Frankfurt/M.: Peter Lang

Benedek A. - Veszelszki Á. (eds.) (2016): In the Beginning Was the Image: The Omnipresence of Pictures: Time, Truth, Tradition (Series Visual Learning 6). Frankfurt/M.: Peter Lang

Benedek A. - Veszelszki Á. (eds.) (2017): Virtual Reality - Real Visuality: Virtual, Visual, Veridical (Series Visual Learning 7). Frankfurt/M.: Peter Lang

Comenius, J. A. (1669): Orbis Sensualium Pictus Trilinguis Hoc est: Omnium Fundamentalium in Mundo Rerum, et in Vita Actionum, Pictura et Nomenclatura. Latina, Germanica et Hungarica. Cum Titulorum juxtá Atque Vocabulorum Indice = Die Sichtbare Welt Dinge, und Lebens Verrichtungen Vorbildung, und, Lateinische, Deutsche, und Ungarische Benamung. Samt Einen Titel- und Wörter-Register = A Látható Világ Háromféle Nyelven, az az: Minden Derekassab ez Világon Lévö Dolgoknak és ez Életben Való Tselekedeteknek le Ábrázolása és Deák, Német és Magyar Megnevezése. A Fellyúl Való Írásoknak és Szóknak Laystromával. Noribergae (Nürnberg): Endterus, http://real-r.mtak.hu/571/

Eco, U. (2016): A tökéletes nyelv keresése. Budapest: Atlantisz

Elkins, J. (ed.) (2007): Visual Practices Across the University. München: Wilhelm Fink Verlag

Ferguson, E. S. (1977): The Mind's Eye: Nonverbal Thought in Technology. Science, 197, 827-836. DOI: 10.1126/science.197.4306.827, https://www.researchgate.net/publication/6110691_The Mind's_Eye_Nonverbal_Thought_in_Technology

Goldhaber, M. H. (2004): The Mentality of Homo Interneticus: Some Ongian Postulates. First Monday, 9, 6, http://journals.uic.edu/ojs/index.php/fm/article/view/1155/1075_

Kop, R. - Hill, A. (2008): Connectivism: Learning Theory of the Future or Vestige of the Past? The International Review of Research in Open and Distributed Learning, 9, 3, DOI: 10.19173/ irrodl.v9i3.523, http://www.irrodl.org/index.php/irrodl/article/view/9.3.4/1137

Nyíri K. (ed.) (2006): Mobile Understanding: The Epistemology of Ubiquitous Communication. Vienna: Passagen Verlag 
Nyíri K. (szerk.) (2007a): Mobiltársadalomkutatás: Paradigmák-perspektívák. Budapest: MTA / T-Mobile. (angolul: Nyíri, 2007b)

Nyíri K. (ed.) (2007b): Mobile Studies: Paradigms and Perspectives. Vienna: Passagen Verlag

Nyíri K. (ed.) (2008a): Integration and Ubiquity: Towards a Philosophy of Telecommunications Convergence. Vienna: Passagen Verlag

Nyíri K. (ed.) (2008b): Engagement and Exposure: Mobile Communication and the Ethics of Social Networking. Vienna: Passagen Verlag

Siemens, G. (2005): Connectivism: A Learning Theory for the Digital Age. International Journal of Instructional Technology and Distance Learning, https:/www.hetl.org/wp-content/uploads/2013/09/HETLReview2013SpecialIssueArticle1.pdf

Vámos T. et al. (2016): Sysbook. Budapest: MTA-BME, http://sysbook.sztaki.hu/index.php_ 